The Journal of

Thoracic and

Cardiovascular

Surgery

Vol 125, No. 1, January 2003

\title{
J. Gordon Scannell, MD (1914-2002)
}

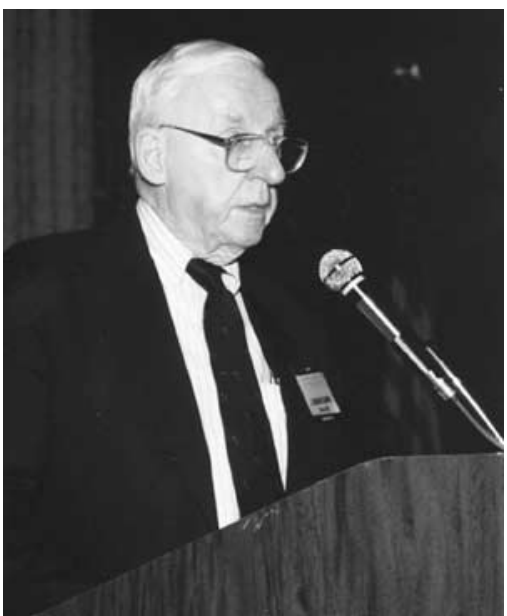

Dr Scannell

J Thorac Cardiovasc Surg 2003;125:1-2

Copyright () 2003 by The American Association for Thoracic Surgery

$0022-5223 / 2003 \$ 30.00+0$

doi: $10.1067 / \mathrm{mtc} .2003 .145$

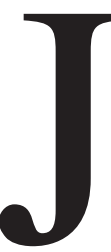

ohn Gordon Scannell, the fifty-seventh president of The American Association for Thoracic Surgery, died in Westwood, Massachusetts, on August 24, 2002, in his eighty-ninth year.

Son of a Boston surgeon and a mother from Prince Edward Island, Dr Scannell was educated successively at Boston Public Latin School, Phillips Exeter Academy, Harvard College, and the Harvard Medical School. There he was awarded the Henry Christian Prize, traditionally given to the fourth-year student with the highest scholastic average.

His entire surgical career was spent, with a single year's exception, at the Massachusetts General Hospital. He was accepted as a surgical intern in 1940, rose to the chief residency on the East Surgical Service in 1944-1946, spent a year studying the anatomy of the right upper lobe with Edward A. Boyden in Minneapolis, then joined the surgical staff at the MGH. He ultimately became clinical professor of surgery at the Harvard Medical School and visiting surgeon at the Massachusetts General Hospital.

He began his surgical internship in September 1940. He was one of the first pair in the new Churchill residency format, an innovative quadrilateral training program in which six interns would be graduated through five full years of service. Although interrupted by World War II, this concept of surgical training remains the basic MGH model today with the position of chief residency to follow in the sixth year.

Dr Scannell's own training was interrupted in the fall of 1941 by a bout with pulmonary tuberculosis. He retreated to the Middlesex Sanitarium, where he spent three months for rest and artificial pneumothorax. The latter was continued until he resumed his residency in January 1943. This experience made him ineligible for military service but also honed his interest in tuberculosis and ultimately in thoracic surgery. Indeed, from 1954 to 1970 he was attending surgeon at the same Middlesex County Sanitarium where he supervised the thoracic surgical training of many MGH residents.

He was closely associated with two former presidents of the AATS: Edward D. Churchill, chief of surgery at MGH, and Richard H. Sweet, preeminent esophageal surgeon. Under Churchill he carried on various duties from supervising the surgical residency to initiating the cardiac surgical program. The first open heart operation was the removal of an intra-atrial myxoma, a first in the United States. In 1965 he volunteered to serve aboard the S.S. Hope for two months in Conakry, Republic of Guinea, in West Africa. From 1965 to 1971 he served on the American Board of Thoracic Surgery. His career spanned the spectrum from tuberculosis to open heart surgery.

His contributions to surgery were recognized by his election to three society presidencies: the Boston Surgical Society, the New England Surgical Society, and The American Association for Thoracic Surgery. It was his election to the latter office in 1978 which he regarded as the pinnacle of his surgical career. His final role as a surgeon, however, was not his least. In 1972 Gerald Austen asked him "to take 
on the directorship of our medical student teaching program in the department of surgery at the MGH." For 14 years he carried out these duties with a skyrocketing in the popularity of the courses.

The final phase of his career included taking on the editorship (1980) of the Harvard Medical Alumni Bulletin, his editing and annotation (1990) of Wanderjahr, The Education of a Surgeon, an account of E. D. Churchill's Moseley Travelling Fellowship, and his role as historian for the AATS with his brief monographs of its early presidents.

The mere recitation of the facts of this man's career fails to provide a true sense of the man. He had a wonderful sense of humor, often dry, but once historically apocryphal. While an undergraduate and a member of The Harvard Lampoon, he was labeled "the cunning fellow" involved in the Boston Transcript story "Handsome Dan, Yale Bulldog Mascot, Stolen." His name never appeared in the extensive Boston newspaper coverage.
One of his colleagues commented "always the gentleman, he could be counted upon for the spontaneous but ideally crafted phrase which was perfectly appropriate for the occasion."

He was a true family man. He and his late wife, Helen (he referred to her as "the big H"), raised seven very successful children, loved their summer retreats together on Prince Edward Island, and engaged in a variety of sports for relaxation: skiing with the Schussverein Ski Club, tennis, and sailing-once transatlantic in a 42-foot sloop. His series of sailboats bore unusual names: Glooscap and Kaloosit. There was time for travel-from the Yucatan to Ireland-even two trips to Baffin Island in what he termed "a sort of Celtic madness." A favorite was retracing the pilgrimage to Santiago Compostela, The Way of St James.

J. Gordon Scannell, a scholarly, articulate, talented, and intriguing man-my great friend!

Earle Wayne Wilkins, MD 